\title{
Pengaruh Likuiditas, Leverage, Aktivitas, dan Profitabilitas terhadap Nilai Perusahaan pada Sektor Barang Konsumsi yang Terdaftar Di Bursa Efek Indonesia Periode 2015-2018
}

\author{
Anju S.M Galingging $^{1^{*}}$, Fery Xaverius Aritonang ${ }^{2}$, Herlina Novita ${ }^{3}$ \\ 1,2,3 Jurusan Akuntansi, Fakultas Ekonomi, Universitas Prima Indonesia, Medan \\ *Correspondence email: anjugalingging @ gmail.com
}

\begin{abstract}
Abstrak. Tujuan penelitian ini adalah untuk mengetahui dan menganalisis pengaruh Likuiditas, Leverage, Aktivitas, dan Profitabilitas terhadap Nilai Perusahaan pada Sektor Barang Konsumsi yang Terdaftar di Bursa Efek Indonesia periode 20152018. Penelitian ini menggunakan metode kuantitatif dengan jenis desciptive. Populasi penelitian ini yaitu Sektor Barang Konsumsi yang terdaftar di Bursa Efek Indonesia periode 2015-2018 sebanyak 50 perusahaan. Pengambilan sampel menggunakan purposive sampling dan didapat sampel penelitian sebanyak 60 sampel dari 15 Sektor Barang Konsumsi dikali 4 tahun. Metode peneleitian ini menggunakan regresi linear berganda.Hasil uji koefisien yang didapat dari nilai Adjusted $R$ Square sebesar 3,7\%, yang artinya variasi variabel Nilai Perusahaan yang dijabarkan oleh variabel independen adalah 96,3\%. Hasil penelitian secara simultan memperlihatkan bahwa Likuiditas, Leverage, Aktivitas, dan Profitabilitas, tidak berpengaruh terhadap Nilai Perusahaan. Sedangkan secara parsial memperlihatkan bahwa Likuiditas, Leverage, dan Profitabilitas tidak berpengaruh dan tidak signifikan terhadap Nilai Perusahaan, namun untuk variabel Aktifitas berpengaruh signifikan terhadap Nilai Perusahaan.
\end{abstract}

Kata kunci: Aktivitas; Leverage; Likuiditas; NP; Profitabilitas

Abstract. The purpose of this study is to determine and analyze the effect of Liquidity, Leverage, Activity, and Profitability on Firm Value in the Consumer Goods Sector Listed on the Indonesia Stock Exchange for the period 2015-2018. This study uses a quantitative method with a desciptive type. The population of this study is the Consumer Goods Sector that is listed on the Indonesia Stock Exchange for the 2015-2018 period, as many as 50 companies. Sampling using purposive sampling and obtained a research sample of 60 samples from 15 sectors of consumer goods multiplied by 4 years. This research method uses multiple linear regression. The coefficient test results obtained from the Adjusted $R$ Square value are 3.7\%, which means that the variation in the Firm Value variable described by the independent variable is $96.3 \%$. The research results simultaneously show that liquidity, leverage, activity, and profitability have no effect on firm value. Meanwhile, partially it shows that liquidity, leverage, and profitability have no and insignificant effect on firm value, but for the activity variable has a significant effect on firm value.

Keywords: Activity: Leverage; Liquidity; NP; Profitability

\section{PENDAHULUAN}

Nilai perusahaan adalah nilai pasar atas surat berharga, hutang dan ekuitas perusahaan yang beredar. Nilai perusahaan sangat penting karena memaparkan tentang kinerja perusahaan yang dapat mempengaruhi pandangan investor tentang perusahaan. Nilai perusahaan yang tinggi akan membuat pasar percaya tidak hanya pada kinerja perusahaan saat ini namun juga prospek perusahaan di masa depan. Nilai perusahaan yang tinggi akan menciptakan harga saham yang tinggi.

Salah satu rasio yang digunakan untuk mengukur nilai perusahaan adalah dengan menggunakan Price to Book Value (PBV). Price to Book Value (PBV) merupakan perbandingan antara harga saham dengan nilai buku saham. Nilai buku perusahaan dihitung sebagai hasil dari pembagian antara ekuitas pemegang saham dengan jumlah yang beredar.

Faktor-faktor yang mempengaruhi nilai perusahaan yaitu likuiditas, leverage, aktivitas dan profitabilitas. Jika rasio likuiditas, manajemen aset, manajemen hutang, dan profitabilitas semuanya terlihat baik dan jika kondisi ini berjalan terus menerus secara stabil maka rasio pasar akan tinggi, harga saham kemungkinan tinggi sesuai dengan yang diperkirakan jika harga saham tinggi maka kemampuan perusahaan membayarkan keuntungan bagi pemegang saham akan meningkat.

Perusahaan yang dipilih penulis pada penelitian ini adalah Sektor Barang Konsumsi yang terdaftar di Bursa Efek Indonesia periode 2015-2018. Perusahaan Barang Konsumsi merupakan salah satu Perusahaan makanan dan minuman yang mempunyai peluang untuk tumbuh dan berkembang.

Gambaran nilai perusahaan likuiditas, leverage, aktifitas dan profitabilitas pada Perusahaan Barang Konsumsi yang terdaftar di Bursa Efek Indonesia periode 2015-2018 dapat dilihat pada tabel fenomena sebagai berikut: 
Anju S.M Galingging et al, Pengaruh Likuiditas, Leverage, Aktivitas, dan Profitabilitas terhadap Nilai Perusahaan pada Sektor Barang Konsumsi yang Terdaftar Di Bursa Efek Indonesia Periode 2015-2018

Tabel 1. Likuiditas, Leverage, Aktifitas, Profitabilitas, dan Nilai Perusahaan pada Sektor Barang Konsumsi Periode 2015-2018

\begin{tabular}{|c|c|c|c|c|c|c|}
\hline Emiten & Periode & Aset Lancar & Total Liabilitas & Penjualan bersih & Laba Bersih & $\begin{array}{l}\text { Harga } \\
\text { Saham }\end{array}$ \\
\hline \multirow{4}{*}{ GGRM } & 2015 & 42.568 .431 .000 .000 & 25.497 .504 .000 .000 & 70.365 .573 .000 .000 & 6.452 .834 .000 .000 & 55.000 \\
\hline & 2016 & 41.933 .173 .000 .000 & 23.387 .406 .000 .000 & 76.274 .147 .000 .000 & 6.672 .682 .000 .000 & 63.900 \\
\hline & 2017 & 43.764 .490 .000 .000 & 24.572 .266 .000 .000 & 83.305 .925 .000 .000 & 7.755 .347 .000 .000 & 83.800 \\
\hline & 2018 & 7.755.347.000.000 & 7.755 .347 .000 .000 & 95.707 .663 .000 .000 & 7.755 .347 .000 .000 & 83.625 \\
\hline \multirow{4}{*}{ HMSP } & 2015 & 29.807 .330 .000 .000 & 5.994.664.000.000 & 89.069.306.000.000 & 10.363 .308 .000 .000 & 3.760 \\
\hline & 2016 & 33.647 .496 .000 .000 & 8.333 .263 .000 .000 & 95.466 .657 .000 .000 & 12.762 .229 .000 .000 & 3.830 \\
\hline & 2017 & 34.180 .353 .000 .000 & 9.028 .078 .000 .000 & 99.091 .484 .000 .000 & 12.670 .534 .000 .000 & 4.730 \\
\hline & 2018 & 37.831 .483 .000 .000 & 11.244.167.000.000 & 106.741 .891 .000 .000 & 13.538 .418 .000 .000 & 3.710 \\
\hline \multirow{4}{*}{ WIIM } & 2015 & 988.814 .005 .395 & 398.981 .064 .485 & 1.839 .419 .574 .956 & 131.081.111.587 & 430 \\
\hline & 2016 & 996.925 .071 .640 & 362.540 .740 .471 & 1.685 .795 .530 .617 & 106.290.306.868 & 440 \\
\hline & 2017 & 861.172 .306 .233 & 247.620 .731 .930 & 1.476.427.090.781 & 40.589 .790 .851 & 290 \\
\hline & 2018 & 888.979 .741 .744 & 250.337 .111 .893 & $1.405 . .384 .153 .405$ & 51.142 .850 .919 & 430 \\
\hline \multirow{4}{*}{ ICBP } & 2015 & 13.961 .500 .000 .000 & 10.173 .713 .000 .000 & 31.741 .094 .000 .000 & 2.923 .148 .000 .000 & 6.737 \\
\hline & 2016 & 15.571 .362 .000 .000 & 10.401 .125 .000 .000 & 34.466 .069 .000 .000 & 3.631 .301 .000 .000 & 8.575 \\
\hline & 2017 & 16.579 .331 .000 .000 & 11.295 .184 .000 .000 & 35.606 .593 .000 .000 & 3.543 .173 .000 .000 & 8.900 \\
\hline & 2018 & 14.121 .568 .000 .000 & 11.660 .003 .000 .000 & 38.413 .407 .000 .000 & 4.658 .781 .000 .000 & 10.450 \\
\hline
\end{tabular}

PT. Gudang Garam Tbk menunjukan total aset lancar tahun 2015 mengalami penurunan pada tahun 2016 sebesar 635.258.000.000 dan pada harga saham di tahun 2015-2016 mengalami kenaikan 8.900, tidak sejalan dengan teori yang menyatakan jika Likuiditas mengalami peningkatan maka nilai harga saham akan menurun yang artinya nilai perusahaan yang tercermin akan meningkatkan harga saham.

PT. Hanjaya Mandala Sampoerna Tbk menunjukan total liablitas tahun 2016 mengalami peningkatan pada tahun 2017 sebesar 694.815.000.000 dan pada harga saham mengalami peningkatan di tahun 2016-2017 sebesar 900 tidak sejalan dengan teori yang menyatakan jika Liabilitas mengalami kenaikan maka akan berdampak terhadap harga saham yang akan menurun.

PT. Wismilak Inti Makmur Tbk menunjukkan penjualan bersih tahun 2015 mengalami penurunan ditahun 2016 sebesar 153.624.044.339 dan harga saham mengalami peningkatan ditahun 2015-2016 sebesar 10 tidak sejalan dengan teori yang menyatakan jika penjualan bersih mengalami kenaikan maka harga saham juga akan meningkat, dimana kemampuan perusahaan menghasilkan penjualan dapat juga mempengaruhi kenaikan harga sahamnya.

PT.Indofood CBP Sukses Makmur Tbk menunjukan total Laba Bersih tahun 2016 mengalami penurunan di tahun 2017 sebesar 88.128.000.000 dan pada harga saham di tahun 2016-2017 mengalami kenaikan sebesar 325, tidak sejalan dengan teori yang menyatakan jika laba bersih mengalami peningkatan maka harga saham juga akan mengalami peningkatan artinya apabila perusahaan menghasilkan laba yang meningkat maka harga saham juga akan meningkat.

\section{METODE}

\section{Tempat Penelitian}

Tempat penelitian dalam penelitian ini adalah Sektor Barang Konsumsi yang terdaftar di Bursa Efek Indonesia.Untuk memperoleh data, penulis mengakses data melalui situs www.idx.co.id yang merupakan website resmi Bursa Efek Indonesia.

\section{Jenis dan Sumber Data}

Dalam penelitian ini, sumber data penelitian adalah laporan keuangan pada Sektor Barang Konsumsi yang terdaftar di Bursa Efek Indonesia dari tahun 20152018 yang telah diaudit.

\section{Metode Pengumpulan Data}

Penelitian ini adalah penelitian kepustakaan (library research). Penelitian kepustakaan dilakukan dengan mengumpulkan data melalui studi penelaah yang dilakukan langsung dengan cara membaca, mencari informasi melalui alat elektronik (browsing) dan mempelajari buku-buku karangan ilmiah, catatan kuliah dan referensi lainnya yang berhubungan dengan pengaruh likuiditas, leverage, aktivitas, profitabilitas dan nilai perusahaan.

\section{Populasi dan Sampel}

Peneliti mengambil tempat penelitian pada Sektor Barang Konsumsi periode 2015-2018 dengan jumlah populasi 50 perusahaan.

Tabel 2. Kriteria Pengambilan Sampel

\begin{tabular}{clc}
\hline No & \multicolumn{1}{c}{ Kriteria } & Jumlah \\
\hline 1 & $\begin{array}{l}\text { Sektor Barang Konsumsi yang terdaftar di } \\
\text { BEI periode 2015-2018 }\end{array}$ & 50 \\
2 & $\begin{array}{l}\text { Sektor Barang Konsumsi yang tidak } \\
\text { menerbitkan Laporan Keuangan setiap tahun }\end{array}$ & $(17)$ \\
& nya & \\
3 & Sektor Barang Konsumsi yang memiliki & $(18)$ \\
& Laba setiap tahun nya \\
Jumlah Perusahaan yang menjadi sampel & 15 \\
Periode Penelitian & 4 Tahun \\
Jumlah pengamatan selama periode penelitian 15 x & 60 Sampel \\
\hline
\end{tabular}

Berdasarkan Kriteria diatas, jumlah populasi yang diperoleh sebanyak 15 perusahaan dikalikan dengan 4 tahun maka diperoleh sampel sebanyak 60 . 
Anju S.M Galingging et al, Pengaruh Likuiditas, Leverage, Aktivitas, dan Profitabilitas terhadap Nilai Perusahaan pada Sektor Barang Konsumsi yang Terdaftar Di Bursa Efek Indonesia Periode 2015-2018

\section{Identifikasi dan Defenisi Operasional Variabel Penelitian}

Variabel yang digunakan dalam penelitian ini terdiri dari satu variabel dependen dan tiga variabel independen.

1. Likuiditas

Menurut Brigham dan Houston (2010), likuiditas merupakan asset yang diperdagangkan dipasar aktif sehingga dapat dikonversi dengan cepat menjadi kas pada harga pasar yang berlaku.

\section{$C R=\frac{\text { Aset lancar }}{\text { Liabilitas jangka pendek }}$}

\section{Leverage}

Menurut Kasmir (2017), leverage merupakan seberapa besar perusahaan dibiayai dengan hutang.

$D E R=\frac{\text { Total Liabilitas }}{\text { Total Ekuitas }}$

\section{Aktivitas}

Menurut Kasmir (2010), Rasio Aktifitas merupakan rasio yang digunakan untuk mengukur efektifitas perusahaan dalam menggunakan aktiva yang dimilikinya.

TATO $=\frac{\text { Penjualan }}{\text { Total Aktiva }}$

\section{Profitabilitas}

Menurut Fahmi (2017), profitabiltas merupakan mengukur efektivitas secara keseluruhan yang ditujukan oleh besar kecilnya tingkat keuntungan yang diperoleh dalam hubungannya dengan penjualan maupn investasi.

\section{$R O E=\frac{\text { Laba Bersih Setelah Pajak }}{\text { Total Ekuitas }}$}

\section{Nilai Perusahaan}

Menurut Fahmi (2017:69), nilai perusahaan merupakan seberapa besar kemampuan perusahaan dalam mempertahankan posisinya didalam industri dan dalam perkembangan ekonomi secara umum.

$$
P B V=\frac{\text { Harga Saham }}{\text { Book Value Per share }}
$$

\section{Uji Asumsi Klasik \\ Uji Normalitas}

Menurut Ghozali (2013:154) Membuktikan adakah terdisitribusi normal dimodel regresi.
Menurut Ghoazali (2013:103), Mengetahui apakah diantara variabel bebas mempunyai korelasi dalam model regresi dimana baiknya diantara variabel tersebut tidak terjadi hubungan.

\section{Uji Autokorelasi}

Menurut Ghozali (2013:107), Untuk mendeteksi gejalla pengganggu pada tahun sekarang dan tahun sebelumnya dalam model regresi.

\section{Uji Heteroskedastisitas}

Menurut Ghozali (2013:134), Uji ini dilakukan untuk mengkur persamaan atau perbedaan varian nilai residual di model regresi.

\section{Model Analisis Data}

$$
\begin{array}{ll}
\mathrm{Y}=\mathrm{a}+\mathrm{b}_{1} \mathrm{X}_{1}+\mathrm{b}_{2} \mathrm{X}_{2}+\mathrm{b}_{3} \mathrm{X}_{3}+\mathrm{b}_{4} \mathrm{X}_{4}+\mathrm{e} \\
\text { Dimana: } & =\text { Nilai Perusahaan } \\
\mathrm{Y} & =\text { Konstanta } \\
\mathrm{a} & =\text { Koefisien Regresi } \\
\mathrm{b}_{1}, \mathrm{~b}_{2}, \mathrm{~b}_{3}, \mathrm{~b}_{4} & =\text { Likuiditas } \\
\mathrm{X}_{1} & =\text { Leverage } \\
\mathrm{X}_{2} & =\text { Aktifitas } \\
\mathrm{X}_{3} & =\text { Profitabilitas } \\
\mathrm{X}_{4} & =\text { Standar Error } \\
\mathrm{e} &
\end{array}
$$

\section{Koefisien Determinasi}

Koefisien determinasi $\left(\mathrm{R}^{2}\right)$ dipakai untuk menguraikan seberapa besar variabel terikat dijabarkan oleh variabel bebas.

\section{Pengujian Hipotesis Secara Simultan}

Menurut Gozhali (2013:96), Membuktikan adakah secara keseluruhan semua variabel mempunyai pengaruh pada variabel Y.

\section{Pengujian Hipotesis Secara Parsial}

Menurut Ghozali (2013:97), Membuktikan adakah setiap variabel penjelas memiliki hubungan pada variabel terikat.

\section{HASIL DAN PEMBAHASAN \\ Statistik Deskriptive} berikut :

Pengolahan data dapat dilihat ditabel deskriptiv

Tabel 3. Descriptive statisitic

\begin{tabular}{|l|l|l|l|l|l|}
\hline & $\mathrm{N}$ & Minimum & Maximum & Mean & Std. Deviation \\
\hline X1 & 60 & .605632 & 9.276535 & 3.09935163 & 1.931286598 \\
$\mathrm{X} 2$ & 60 & .076125 & 2.654552 & .64921212 & .570924466 \\
$\mathrm{X} 3$ & 60 & .546345 & 2.391882 & 1.22763168 & .465378771 \\
$\mathrm{X} 4$ & 60 & .033882 & 1.726679 & .25196587 & .353678261 \\
$\mathrm{Y}$ & 60 & .338962 & 6.724245 & 2.22239010 & 1.643081894 \\
\hline
\end{tabular}

Sumber: Hasil SPSS 23

\section{Uji Multikolinearitas}


Anju S.M Galingging et al, Pengaruh Likuiditas, Leverage, Aktivitas, dan Profitabilitas terhadap Nilai Perusahaan pada Sektor Barang Konsumsi yang Terdaftar Di Bursa Efek Indonesia Periode 2015-2018

Pada tabel tersebut terlihat nilai minimum, maksimum, nilai rata-rata (mean), dan standar deviasi dari variabel Likuiditas, Leverage, Aktivitas, dan Profitabilitas dengan rincian sebagai berikut :

1. Variabel Likuiditas memiliki nilai minimum sebesar 0,605632 oleh PT Unilever Indonesia, Tbk. Tahun 2016 dan nilai maksimum sebesar 9,276535 oleh PT Industri Jamu dan Farmasi Sido Muncul, Tbk. pada tahun 2015, dengan nilai mean 3,09935163 dan nilai standar deviasi sebesar 1,931286598.

2. Variabel Leverage memiliki nilai minimum sebesar 0,076125 oleh PT Industri Jamu dan Farmasi Sido Muncul, Tbk. Tahun 2015 dan nilai maksimum sebesar 2,654552 oleh PT Unilever Indonesia, Tbk. pada tahun 2017, dengan nilai mean 0,64921212 dan nilai standar deviasi sebesar 0,570924466.

3. Variabel Aktivitas memiliki nilai minimum sebesar 0,546345 oleh PT Nippon Indosari Corpindo, Tbk. Tahun 2017 dan nilai maksimum sebesar 2,391882 oleh PT Unilever Indonesia, Tbk. pada tahun 2016, dengan nilai mean 1,22763168 dan nilai standar deviasi sebesar 0,465378771.

4. Variabel Profitabilitas memiliki nilai minimum sebesar 0,033882 oleh PT Kino Indonesia, Tbk. Tahun 2017 dan nilai maksimum sebesar 1,726679 oleh PT Gudang Garam, Tbk. pada tahun 2018, dengan nilai mean 0,25196587 dan nilai standar deviasi sebesar 0,353678261.

5. Variabel Nilai Perusahaan memiliki nilai minimum sebesar 0,338962 oleh PT Indofood Sukses Makmur, Tbk. Tahun 2018 dan nilai maksimum sebesar 6,724245 oleh PT Kimia Farma, Tbk. pada tahun 2016, dengan nilai mean 2,22239010 dan nilai standar deviasi sebesar 1,643081894.

\section{Uji Asumsi Klasik}

\section{Uji Normalitas}

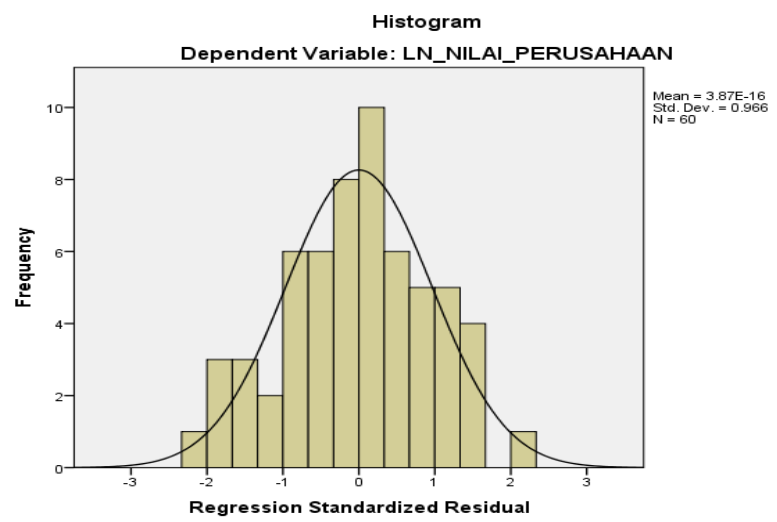

Gambar 1. Histogram Data

Sumber : Hasil SPSS 23

Gambar diatas dari uji normalitas dengan grafik histogram dapat dilihat bahwa goresan kurva yang condong simetris dan terbentuk seperti lonceng, maka dapat disimpulkan bahwa uji tersebut memiliki distribusi normal.

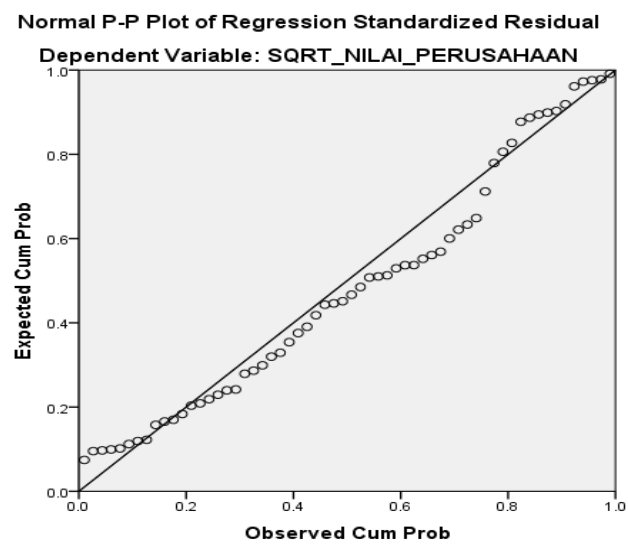

Gambar 2. PP-Plot

Sumber : Hasil SPSS 23

Hasil uji pada Gambar diatas dapat dilihat bahwa data berupa bintik mendekati garis disekitar diagonal, sehingga disimpulkan bahwa uji tersebut berdistirbusi normal.

Tabel 4. Kolmogrov Smirnov

One Sample Kolmogrov Smirnov Test

\begin{tabular}{|ll|l|}
\hline & & $\begin{array}{l}\text { Unstandardized } \\
\text { Residual }\end{array}$ \\
\hline $\mathrm{N}$ & & 60 \\
Normal & Mean & .0000000 \\
Parameters ${ }^{\mathrm{a} b}$ & Std. Deviation & .71948001 \\
Most Extreme & Absolute & .056 \\
Differences & Positive & .039 \\
& Negative & -.056 \\
Test Statistic & .056 \\
Asymp. Sig. (2-tailed) & $.200^{\text {c,d }}$ \\
\hline
\end{tabular}

Sumber: Hasil SPSS 23

Berdasarkan pada tabel KS diatas nilai sig nya sebesar 0.200 maka diatas 0.05 dapat disimpulkan bahwa uji tersebut berdistribusi normal.

\section{Uji Multikolinearitas}

Tabel 5. Uji Multikolinearitas

Coefficients $^{\mathrm{a}}$

\begin{tabular}{|c|c|c|c|}
\hline \multirow{2}{*}{\multicolumn{2}{|c|}{ Model }} & \multicolumn{2}{c|}{ Collinearity Statistics } \\
\cline { 3 - 4 } & & Tolerance & VIF \\
\hline & LN_LIKUIDIUTAS & .190 & 5.269 \\
\hline 1 & LN_LEVERAGE & .193 & 5.181 \\
\hline & LN_AKTIVITAS & .568 & 1.759 \\
\hline & LN_PROFITABILITAS & .532 & 1.879 \\
\hline
\end{tabular}

Sumber: Hasil SPSS 23

Berdasarkan penjelasan diatas, nilai tolerance variabel Likuiditas sebesar 5,269, Leverage sebesar 5,181, Aktivitas sebesar 1.759, dan Profitabilitas sebesar 1.879 lebih besar dari 0,10 dan nilai VIF untuk variabel likuiditas sebesar 0,190, Leverage 0,193, Aktivitas sebesar 0,568 dan Profitabilitas sebesar 0,532 sehingga 
Anju S.M Galingging et al, Pengaruh Likuiditas, Leverage, Aktivitas, dan Profitabilitas terhadap Nilai Perusahaan pada Sektor Barang Konsumsi yang Terdaftar Di Bursa Efek Indonesia Periode 2015-2018

terlihat lebih kecil dari 10, artinya tidak terjadi multikolinearitas.

\section{Uji Autokorelasi}

Tabel 6. Uji Autokorelasi

Model Summary ${ }^{b}$

\begin{tabular}{|c|c|c|c|c|c|}
\hline Model & $\mathrm{R}$ & $\mathrm{R}$ Square & $\begin{array}{c}\text { Adjusted R } \\
\text { Square }\end{array}$ & $\begin{array}{c}\text { Std. Error of the } \\
\text { Estimate }\end{array}$ & $\begin{array}{c}\text { Durbin- } \\
\text { Watson }\end{array}$ \\
\hline 1 & $.320^{\mathrm{a}}$ & .103 & .037 & .74518 & 2.018 \\
\hline
\end{tabular}

Sumber: Hasil SPSS 23

DW senilai 2,018, ditabel DW $\mathrm{k}=4$ dan $\mathrm{n}=60$ besar $\mathrm{dl}=1,4443$ dan $\mathrm{du}=1,7274 ; 4-\mathrm{dl}=2,5557$, dan $4-\mathrm{du}=2,2726$. Dari kriteria tersebut pada pedoman DW maka nilai du $<$ dw $<4$ - du atau 1,7274 $<2,018<$ 2,2726 maka hasil autokorelasi menunjukkan tidak terjadi autokorelasi positif dan negatif.

\section{Uji Heterokedastisitas}

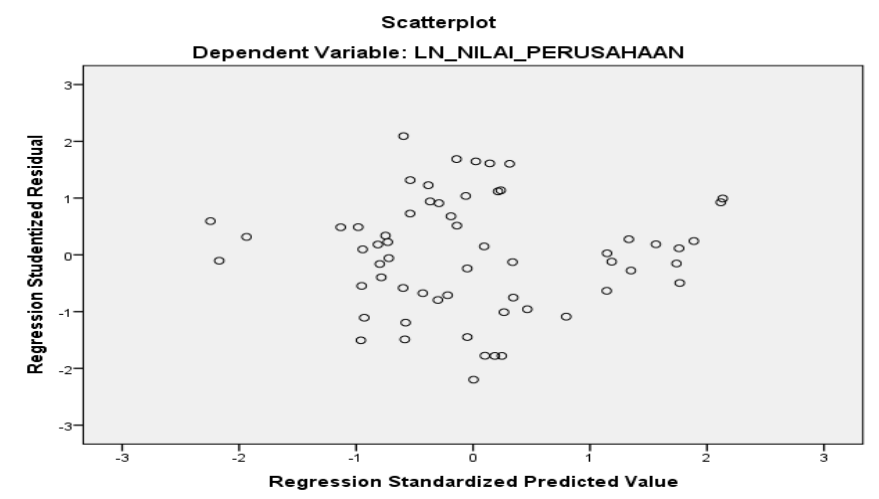

Gambar 3. Uji Heterokedastisitas Sumber: Hasil SPSS 23

Pada gambar terlihat bahwa titik-titik tersebar dan tidak ada berkumpul dalam satu titik, maka grafik scatterplot disimpulkan tidak mengalami heterokedastisitas.

\section{Uji Gletser}

Tabel 7. Uji Gletser

Coefficients ${ }^{\mathbf{a}}$

\begin{tabular}{|l|l|l|l|l|l|}
\hline \multirow{2}{*}{ Model } & \multicolumn{2}{|l|}{ Unstandardized Coefficients } & Standardized Coefficients & \multirow{2}{*}{} & \multirow{2}{*}{ Sig. } \\
\cline { 2 - 4 } & $\mathrm{B}$ & Std. Error & Beta & & \\
\hline (Constant) & .547 & .203 & & 2.702 & .009 \\
LN_LIKUIDITAS & .127 & .203 & .187 & .623 & .536 \\
LN_LEVERAGE & .206 & .156 & .392 & 1.320 & .192 \\
LN_AKTIVITAS & .131 & .215 & .106 & .611 & .544 \\
LN_PROFITABILITAS & -.023 & .088 & -.047 & -.265 & .792 \\
\hline
\end{tabular}

Sumber: Hasil SPSS 23

Berdasarkan penjelasan diatas mengatakan nilai signifikan untuk variabel Likuiditas sebesar 0,536, variabel Leverage sebesar 0,192, variabel Aktifitas sebesar 0,544, dan variabel Profitabilitas sebesar 0,792 melebihi 0,05, dengan ini data tersebut terhindar dari heterokedastisitas.

\section{Hasil Analisis Data Penelitian Model Penelitian}

Tabel 8. Persamaan Regresi

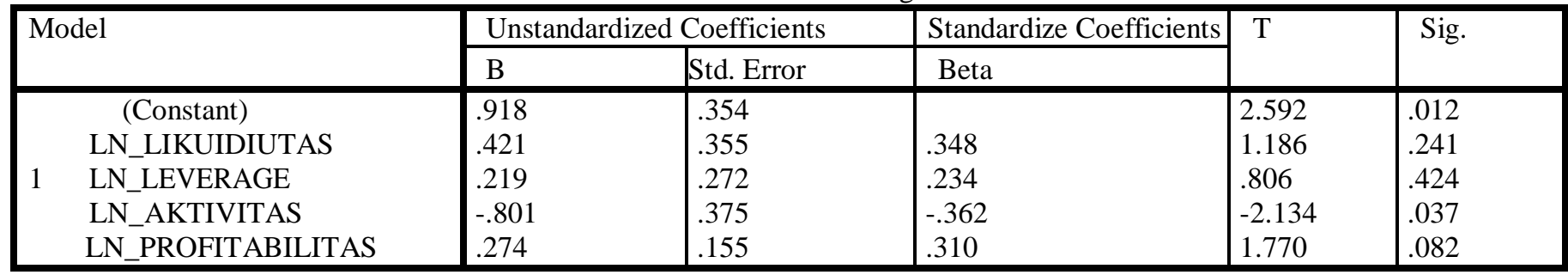

Sumber: Hasil SPSS 23

\section{LN NILAI PERUSAHAAN $=0,918+0,421$ LN LIKUIDITAS $+0,219$ LN LEVERAGE- 0,801LNAKTIVITAS + 0,274 LN PROVITABILITAS}

Dari persamaan regresi linear berganda tersebut:

1. Nilai konstanta (a) menunjukkan nilai sebesar 0,918 satuan mengatakan jika variabel Likuiditas, Leverage, Aktivitas, dan profitabilitas dianggap 0, maka Nilai Perusahaan pada Sektor Barang Konsumsi yang terdaftar di BEI sebesar 0,918.

2. Koefisien regresi Likuiditas sebesar 0,421 satuan mengatakan setiap kenaikan variabel Likuiditas sebesar $1 \%$ akan menyebabkan kenaikan Nilai Perusahaan sebesar 0,421 dengan anggapan variabel independen adalah nol. 
Anju S.M Galingging et al, Pengaruh Likuiditas, Leverage, Aktivitas, dan Profitabilitas terhadap Nilai Perusahaan pada Sektor Barang Konsumsi yang Terdaftar Di Bursa Efek Indonesia Periode 2015-2018

3. Koefisien regresi Leverage sebesar 0,219 satuan mengatakan setiap kenaikan variabel Leverage sebesar $1 \%$ akan menyebabkan kenaikan Nilai Perusahaan sebesar 0,219 dengan anggapan variabel independen adalah nol.

4. Koefisien regresi Aktivitas sebesar -0,801 satuan mengatakan setiap kenaikan variabel Aktivitas sebesar $1 \%$ akan menyebabkan kenaikan Nilai Perusahaan sebesar -0,801 dengan anggapan variabel independen adalah nol.

5. Koefisien regresi Profitabilitas sebesar 0,274 satuan mengatakan setiap kenaikan variabel Profitabilitas sebesar $1 \%$ akan menyebabkan kenaikan Nilai Perusahaan sebesar 0,274 dengan anggapan variabel independen adalah nol.

\section{Koefisien Determinasi Hipotesis Analisis Koefisien Determinasi $\left(\mathbf{R}^{2}\right)$}

Tabel 9. Uji Koefisien Determinasi

\begin{tabular}{|l|l|l|l|l|}
\hline Model & $\mathrm{R}$ & $\mathrm{R}$ Square & $\begin{array}{l}\text { Adjusted } \\
\text { R Square }\end{array}$ & $\begin{array}{l}\text { Std. Error of the } \\
\text { Estimate }\end{array}$ \\
\hline 1 & $.320^{\mathrm{a}}$ & .103 & .037 & .74518 \\
\hline
\end{tabular}

Sumber: Hasil SPSS 23

Dari tabel terlihat nilai Adjusted R Square sebesar 0,037. Hal ini berarti 3,7\% dari variabel dependen yang dijelaskan oleh variabel independen, sedangkan sisanya
96,3\% dijelaskan oleh variabel lainnya diluar dari variabel yang diteliti misalnya penjualan atas laba bersih.

\section{Pengujian Hipotesis Secara Simultan (Uji F)}

Tabel 10. Uji F

\begin{tabular}{|c|c|c|c|c|c|}
\hline Model & Sum of Squares & Df & $\begin{array}{l}\text { Mean } \\
\text { Square }\end{array}$ & $\mathrm{F}$ & Sig. \\
\hline $\begin{array}{ll} & \text { Regression } \\
1 & \text { Residual } \\
& \text { Total } \\
\end{array}$ & $\begin{array}{l}3.489 \\
30.541 \\
34.030\end{array}$ & $\begin{array}{c}4 \\
55 \\
59\end{array}$ & $\begin{array}{l}.872 \\
.555\end{array}$ & 1.571 & $.195^{\mathrm{b}}$ \\
\hline
\end{tabular}

Sumber: Hasil SPSS 23

Dari keterangan tabel menunjukkan nilai $\mathrm{F}_{\text {hitung }}$ 1,571 dengan tingkat signifikan 0,195. Sedangkan $F_{\text {tabel }}$ 2,54 dengan nilai signifikan 0,05 . Hal ini menunjukkan bahwa $F_{\text {hitung }}<F_{\text {tabel }}$ atau 1,571 $<2,54$ dan 0,195 $>0,05$ yang berarti bahwa $\mathrm{H}_{0}$ diterima dan $\mathrm{H}_{\mathrm{a}}$ ditolak yang berarti secara simultan Likuiditas, Leverage, Aktivitas, dan Profitabilitas tidak berpengaruh dan tidak signifikan terhadap Nilai Perusahaan pada Sektor Barang Konsumsi yang terdaftar di BEI periode 2015-2018.

\section{Pengujian Hipotesis Secara Parsial (Uji T)}

Tabel 11. Uji $\mathrm{T}$

\begin{tabular}{|c|c|c|c|c|c|c|}
\hline \multirow{2}{*}{\multicolumn{2}{|c|}{ Model }} & \multicolumn{2}{|c|}{ Unstandardized Coefficients } & \multirow{2}{*}{$\begin{array}{l}\text { Standardize Coefficients } \\
\text { Beta }\end{array}$} & \multirow[t]{2}{*}{$\mathrm{T}$} & \multirow[t]{2}{*}{ Sig. } \\
\hline & & $\mathrm{B}$ & Std. Error & & & \\
\hline 1 & $\begin{array}{l}\text { (Constant) } \\
\text { LN_LIKUIDIUTAS } \\
\text { LN_LEVERAGE } \\
\text { LN_AKTIVITAS } \\
\text { N_PROFITABILITAS }\end{array}$ & $\begin{array}{l}.918 \\
.421 \\
.219 \\
-.801 \\
.274\end{array}$ & $\begin{array}{l}.354 \\
.355 \\
.272 \\
.375 \\
.155\end{array}$ & $\begin{array}{l}.348 \\
.234 \\
-.362 \\
.310\end{array}$ & $\begin{array}{l}2.592 \\
1.186 \\
.806 \\
-2.134 \\
1.770\end{array}$ & $\begin{array}{l}.012 \\
.241 \\
.424 \\
.037 \\
.082\end{array}$ \\
\hline
\end{tabular}

Sumber : Hasil SPSS 23

Dari tabel, Nilai $T_{\text {tabel }}$ Untuk signifikan 0,05 pada derajat bebas 60 adalah 2,00030. Dengan demikian hasil Uji T sebagai berikut :

1. Hasil perhitungan Uji $\mathrm{T}$ untuk variabel Likuiditas secara parsial diperoleh nilai thitung 1,186 dengan nilai signifikan 0,241 maka $t_{\text {hitung }}<\mathrm{t}_{\text {tabel }}$ atau $1,186<$ 2,00030 dengan signifikan $0,241>0,05$ dengan kriteria $\mathrm{H}_{0}$ diterima dan $\mathrm{H}_{\mathrm{a}}$ ditolak yang artinya Likuiditas tidak berpengaruh dan tidak signifikan terhadap Nilai Perusahaan pada Sektor Barang Konsumsi yang terdaftar di BEI periode 2015-2018.

2. Hasil perhitungan Uji $\mathrm{T}$ untuk variabel Leverage secara parsial diperoleh nilai thitung 0,806 dengan nilai signifikan 0,424 maka $t_{\text {hitung }}<t_{\text {tabel }}$ atau $0.806<$ 2,00030 dengan signifikan 0,424>0,05 dengan kriteria $\mathrm{H}_{0}$ diterima dan $\mathrm{H}_{\mathrm{a}}$ ditolak yang artinya Leverage tidak berpengaruh dan tidak signifikan terhadap Nilai Perusahaan pada Sektor Barang Konsumsi yang terdaftar di BEI periode 2015-2018.

3. Hasil perhitungan Uji $T$ untuk variabel Aktivitas secara parsial diperoleh nilai $t_{\text {hitung }}-2,134$ dengan nilai signifikan 0,037 maka $-\mathrm{t}_{\text {hitung }}<-\mathrm{t}_{\text {tabel }}$ atau $-2,134$ $<-2,00030$ dengan signifikan $0,037<0,05$ dengan kriteria $\mathrm{H}_{0}$ ditolak dan $\mathrm{H}_{\mathrm{a}}$ diterima yang artinya Aktivitas berpengaruh secara negatif dan signifikan terhadap Nilai Perusahaan pada Sektor Barang Konsumsi yang terdaftar di BEI periode 2015-2018.

4. Hasil perhitungan Uji T untuk variabel Profitabilitas secara parsial diperoleh nilai thitung 1,770 dengan nilai signifikan 0,082 maka $t_{\text {hitung }}<t_{\text {tabel }}$ atau $1,770<$ 2,00030 dengan signifikan 0,082>0,05 dengan kriteria $\mathrm{H}_{0}$ diterima dan $\mathrm{H}_{\mathrm{a}}$ ditolak yang artinya Profitabilitas tidak berpengaruh dan tidak signifikan terhadap Nilai Perusahaan pada Sektor Barang Konsumsi yang terdaftar di BEI periode 2015-2018. 


\section{SIMPULAN}

Pengaruh Likuiditas terhadap Nilai Perusahaan

Hasil pengujian ini mengatakan secara parsial Likuiditas tidak berpengaruh dan tidak signifikan terhadap Nilai Perusahaan pada Sektor Barang Konsumsi yang terdaftar di BEI periode 2015-2018.

Hasil penelitian ini tidak sependapat dengan Astutik (2017) yaitu Likuiditas berpengaruh negatif namun tidak signifikan terhadap Nilai Perusahaan pada Perusahaan Industri Manufaktur yang listing di BEI.

\section{Pengaruh Leverage terhadap Nilai Perusahaan}

Hasil pengujian ini mengatakan secara parsial Leverage tidak berpengaruh dan tidak signifikan terhadap Nilai Perusahaan pada Sektor Barang Konsumsi yang terdaftar di BEI periode 2015-2018.

Hasil penelitian ini tidak sependapat dengan Pratama (2016) yang mengatakan Leverage Berpengaruh terhadap Nilai Perusahaan dengan judul pengaruh ukuran perusahaan dan leverage terhadap nilai perusahaan dengan profitabilitas sebagai variabel.

\section{Pengaruh Aktivitas terhadap Nilai Perusahaan}

Hasil pengujian ini mengatakan secara parsial Aktivitas berpengaruh dan signifikan terhadap Nilai Perusahaan pada Sektor Barang Konsumsi yang terdaftar di BEI periode 2015-2018.

Hasil penelitian ini sependapat dengan Rinnaya (2016) yang mengatakan Aktivitas berpengaruh terhadap Nilai Perusahaan dengan judul pengaruh profitabilitas, rasio aktivitas, keputusan pendanaan, keputusan investasi terhadap nilai perusahaan.

\section{Pengaruh Profitabilitas terhadap Nilai Perusahaan}

Hasil pengujian ini mengatakan secara parsial Profitabilitas tidak berpengaruh dan tidak signifikan terhadap Nilai Perusahaan pada Sektor Barang Konsumsi yang terdaftar di BEI periode 2015-2018.

Hasil penelitian ini tidak sependapat dengan Hermuningsih (2012) yang mengatakan profitabilitas berpengaruh terhadap nilai perusahaan dengan judul pengaruh profitabilitas, size terhadap nilai perusahaan dengan struktur modal sebagai variabel intervening.

\section{DAFTAR PUSTAKA}

Astuti, D. (2017). Pengaruh Aktivitas Rasio Keuangan Terhadap Nilai Perusahaan (Studi pada Industri Manufaktur). Vol 9, No.1, Edisi Februari 2017:32-49. Jurnal STIE Semarang.

Brigham dan Houston. 2010. Dasar-dasar Manajemen Keuangan. Jakarta:Salemba empat.

Fahmi, Irvan. 2017. Analisis Kinerja Keuangan : Panduan bagi Akedemisi, Manager, dan Investor untuk Menilai dan Menganalisis Bisnis dari Aspek Keuangan. Bandung: Alvabeta.
Ghozali, Imam. 2013. Aplikasi Analisis Multivariat dengan program IBM SPSS Edisi 7. Semarang: Penerbit Universitas Diponegoro.

Hermuningsih, S. (2012). Pengaruh Profitabilitas, Size terhadap Nilai Perusahaan dengan Struktur Modal sebagai Variabel Intervening. Vol. 16, No. 2 Juli 2012, 232-242. Jurnal Siasat Bisnis.

Kasmir. (2010). Analisis Laporan Keuangan. Jakarta: PT. Raja Grafindo Persada.

Kasmir. 2017. Pengantar Manajemen Keuangan. Cetakan keenam. Jakarta:Kencana.

Permana, A, B, N. Rahyuda, H. (2019). Pengaruh Profitabilitas, Solvabilitas, Likuiditas, dan Invlasi Terhadap Nilai Perusahaan. E-Jurnal Manajemen Unud, Vol, No. 32019 : 1577-1607.

Pratama, A, B, G, I. dan Wiksuana, B, G, I. (2016) Pengaruh Ukuran Perusahaan dan Leverage terhadap Nilai Perusahaan dengan Profitabilitas sebagai Variabel Mediasi. Vol. 5, No.2, 2016:1338-1367. E-Jurnal Manajemen Unud.

Rinnaya, Y, I. Andini, R. Oemar, A.(2016). Pengaruh Profitabilitas, Rasio Aktivitas, Keputusan pendanaan, Keputusan Investasi terhadap Nilai Perusahaan (Studi Empiris pada Perusahaan Manufaktur yang Terdaftar di BEI tahun 20102014). Vol. 2, No. 2, Maret 2016. Journal of Accounting.

Situs Bursa Efek Indonesia http://www.idx.co.id 